sphenoid rather elongate and much constricted behind the basipterygoid processes, intermediate between Metopoceros and Ctenosaura.

7. Ctenosaura, Wiegm.-Lateral teeth with three or four cusps. Præmaxillary extending as far as the posterior border of the nasal fossæ; the length of the latter less than their distance from the orbits. Præfrontal not entering the nasal fossa. Postfronto-squamosal arch slender, at least as long as the orbit; postfrontal longer than deep. Transpalatine not in contact with palatine. Basisphenoid elongate and much constricted behind the basipterygoid processes.

The skull of Cyclura is figured by Brühl, 'Zootomie,' pl. cxliv., as that of Iguana tuberculata. An excellent figure of the skull of Metopoceros is given by Cuvier, Oss. Foss. v. pt. 2, pl. xvi. figs. 23-26. In the figure published by Günther, Trans. Zool. Soc. xi. pl. xliv., the parietal foramen is represented, through an error of the artist in the drawing of the sutures, as in the frontal bone, whilst, as in other Iguanas, it is situated between frontal and parietal. The three possible positions of the parietal foramen are to be found in the family Iguanidæ, viz. between frontal and parietal (nearly all the genera), in the frontal (Basiliscus, Corythophanes), or in the parietal (Chamceleolis, Anolis). Xiphocercus and Norops, though so closely allied to Anolis, have the foramen between frontal and parietal.

L. - The Genera Trigaster and Benhamia. By W. Blaxland Benham, D.Sc., Assistant to the Jodrell Professor of Zoology, University College, London.

IN 1886 I described an earthworm from the island of St. Thomas, West Indies, its most remarkable peculiarity (at that stage of our knowledge of earthworms) being the possession of three separate gizzards; to this worm I gave the name Trigaster Lankesteri* ${ }^{*}$. Its other characters ally it to Acanthodrilus, e. g. the two pairs of cylindrical and convoluted prostates and the condition of the nephridia.

In 1889 Dr. Michaelsen, of Hamburg, described a worm, under the name of Benhamia rosea $\dagger$, which in some respects

* Quart. Journ. Micr. Sci. xxvii.

† Jahrb. d. Hamburg. wiss. Anstalten, vi. 
agrees with Trigaster Lankesteri, but differs in several of the characteristic features of the latter, one being the possession of two gizzards and another the extent of the clitellum. Dr. Michaelsen, however, suggested the suppression of the name Trigaster in favour of Benhamia, on the ground that the former generic name no longer holds good for his new species on account of its significance.

In my recent article, "An Attempt to Classify Earthworms" (Quart. Journ. Micr. Sci. xxxii.), I have included his species under the older name Trigaster; this I did believing that, although the name had no longer a literal significance for the new species, I was justified in retaining the prior name. Dr. Michaelsen has published descriptions of other species of the same genus, and after communication with him and with Dr. Rosa, of Turin, and a careful perusal of his papers, I am led to regard the species of Benhamia as distinct from Trigaster. The two genera are not synonymous, as would appear from his article, but are distinct though very closely allied forms; and perhaps they should both be regarded as subgenera of Acanthodrilus. At present, however, I would consider them as distinct.

The following characters are common to the three genera, together with Deinodrilus (Beddard) :-

(1) Nephridia in form of a network.

(2) Two pairs of coiled cylindrical prostates in somites xvii. and xix.

(3) Two pairs of spermathecæ.

Deinodrilus differs from the rest in possessing twelve setæ per somite and in its short clitellum (xiv. to xvi.).

Acanthodrilus has a single gizzard and behind it paired calciferous glands.

The anterior nephridia form a compact mass or pepto-neph communicating (? always) with the pharynx.

The spermathecæ lie in somites vii. and viii.

The two sperm-ducts of each side are separate till near the sperm-pore.

\section{Trigaster :-}

1. The clitellum is extremely long, occupying somites xiii. to $\mathrm{xl}$.

2. There are three separate gizzards, in somites vii., viii., and ix.

3. There are no calciferous glands. 
4. The two pairs of spermathecæ lie in viii. and ix., are globular, have no appendix or swellings or diverticula near the external apertures, which are placed

5. No penial setæ. posteriorly, i. e. between viii./ix. and ix./x.

6. No dorsal pores.

\section{Benhamia:-}

1. The clitellum occupies at most eight somites, varying, however, in extent and limits (xiii. to xix. or xiv. to $\mathrm{xxi}$.).

2. There are only two gizzards.

3. Calciferous glands are present.

4. The spermathecæ are rather ovoid than globular and have appendices or diverticula to their narrowed ducts, which open externally on the anterior boundaries of their somites, viz. vii./viii. and viii./ix.

5. Penial setæ in special sacs are present in relation to the prostate.

6. Dorsal pores are present, at any rate in some of the species.

Both genera, however, agree in having all the eight setæ in each somite close together on the ventral surface, in having: a pit or fossa, at the bottom of which the prostates and spermiducal pores open externally, and in these two characters they differ from Acanthodrilus.

The genus Trigaster includes at present only one species, T. Lankesteri, Benham, 1886, from St. Thomas, West Indies.

The genus Benhamia includes the following species, all being from West Africa, with the exception of the last, the locality of which is unknown, and is merely a matter of speculation :-

1. B. rosea, Michaelsen, 1889.

2. B. Stuhlmanni, Michaelsen, 1890.

3. B. affinis, Michaelsen, 1890.

4. B. Schlegelii, Horst, 1884.

5. B. Büttikoferi, Horst, 1884.

6. B. Beddardi, Horst, 1888.

7. B. scioana, Rosa, 1888.

8. B. Godeffroyi, Michaelsen, 1890. 
The species 4, 5, 6, 7 were originally described under the genus Acunthodrilus (see my article in Quart. Journ. Micr. Sci. xxxii.), but have been transferred on account of their possessing two gizzards and a genital fossa.

October 17, 1890.

LI.-On a new Species of Gyracanthus.
By R. H. Traquair, M.D., F.R.S.

In their recently published 'Catalogue of British Fossil Vertebrata' Messrs. Smith Woodward and Sherborne state concerning the spine from Burdiehouse figured by Hibbert (Trans. Roy. Soc. Edinb. xiii. pl. xi. fig. 1), and referred by Agassiz to his Gyracanthus formosus, that it "is of doubtful species." This spine is in the collection of the Museum of Science and Art, and I had long been of opinion that neither it nor any other specimen of Gyracanthus from the Calciferous Sandstone series could be referred to the same species as that from the Coal-measures figured by Agassiz as such (Poiss. Foss. t. iii. tab. v. figs. 2-6), and which, on the other hand, must also include his $G$. formosus. Lately a considerable number of Gyracanthus spines have occurred in the "Dunnet" shale at Straiton, which clearly belong to the same species as those from Burdiehouse, and enable one to have a still better idea of its characters and configuration.

Those spines resemble G. formosus (incl. tuberculatus) in the nature of their ornament, and though most of the Burdiehouse specimens are eroded and worn, that figured by Hibbert has the tuberculation of the ridges in places exceedingly well marked. But from G. formosus the species differs in having the basal or inserted portion very small, and again in the usual want of that lateral curvature which is so constant a feature in all examples of that species which have attained any size. The antero-posterior curvature is usually present, but only in one specimen out of many have I observed any pronounced lateral flexure. Like $G$. formosus they are frequently worn at the tips, and all are bilaterally unsymmetrical.

As there is no doubt that we have here a species which has not hitherto been named or defined, I propose for it the name of Gyracanthus rectus.

Not uncommon in the Calciferous Sandstone series of the east of Scotland. Besides Burdiehouse and Straiton, the following localities may be noted:-Burntisland, Pittenweem, St. Andrews.

Ann. \& Mag. N. Hist. Ser. 6, Vol. vi. 


\section{$2 \mathrm{BHL}$ Biodiversity Heritage Library}

Benham, W. B. 1890. "L.-The genera Trigaster and Benhamia." The Annals and magazine of natural history; zoology, botany, and geology 6, 414-417. https://doi.org/10.1080/00222939008694057.

View This Item Online: https://www.biodiversitylibrary.org/item/88261

DOI: https://doi.org/10.1080/00222939008694057

Permalink: https://www.biodiversitylibrary.org/partpdf/65103

\section{Holding Institution}

Smithsonian Libraries

\section{Sponsored by}

Smithsonian

\section{Copyright \& Reuse}

Copyright Status: Public domain. The BHL considers that this work is no longer under copyright protection.

This document was created from content at the Biodiversity Heritage Library, the world's largest open access digital library for biodiversity literature and archives. Visit BHL at https://www.biodiversitylibrary.org. 